\title{
GINGIVAL EPITHELIUM ATTACHMENT TO WELL - OR PARTIALLY - CURED RESIN COMPOSITES
}

\author{
E. Boloori ${ }^{1,2, *}$, T. Schoenmaker ${ }^{1}$, C.J. Kleverlaan², B.G. Loos $^{1}$ and T.J. de Vries ${ }^{1}$ \\ ${ }^{1}$ Department of Periodontology, Academic Center for Dentistry Amsterdam (ACTA), \\ University of Amsterdam and Vrije Universiteit Amsterdam, Amsterdam, the Netherlands \\ ${ }^{2}$ Department of Dental Materials Science, Academic Center for Dentistry Amsterdam (ACTA), \\ University of Amsterdam and Vrije Universiteit Amsterdam, Amsterdam, the Netherlands
}

\begin{abstract}
Ideal restoration material for caries would allow attachment of gingival epithelia. The attachment of epithelial cells to specimens of the 4 most commercially used well- or partially-cured resin composites, with and without TEGDMA, was assessed. Effects of resin composite on the Ca9-22 gingival epithelial cell-line were assessed by measuring the cytotoxicity, viability and gene expression for attachment, apoptosis, ROS-production, pro-inflammatory cytokines, and matrix metalloproteinases. As controls, cells on tissue culture plastic or bovine tooth enamel specimens were used. Significantly less cell attachment was measured on freshly made resin-composite specimens. Concomitantly, significantly higher cytotoxicity was measured in the presence of freshly made resin-composite specimens. However, after $8 \mathrm{~d}$ of leakage, the cell attachment to and cytotoxicity of the resin composite was comparable to bovine tooth enamel. Significantly higher expressions of IL6, MMP2, BCL6 and ITGA4 were measured in cells attached to resin-composite surfaces than controls. There were no significant differences between the results using different conditions of resin composite, with or without TEGDMA and well or partially cured. Less cell attachment and presence of more inflammatory markers were observed on all freshly-made resin-composite surfaces. However, after a leakage period attachment of cells to the resin composite improved to the level of natural tooth materials such as enamel. This indicated that the negative effects of resin composites on epithelial cells might be transient.
\end{abstract}

Keywords: Gingiva, inflammation, cytokines, restorative materials, composite materials.

*Address for correspondence: Elmira Boloori, Department of Periodontology, Academic Center for Dentistry Amsterdam (ACTA), Gustav Mahlerlaan 3004, 1081 LA Amsterdam, the Netherlands.

Telephone number: +31 205980158 Email: e.boloori@acta.nl

Copyright policy: This article is distributed in accordance with Creative Commons Attribution Licence (http://creativecommons.org/licenses/by-sa/4.0/).

\section{Introduction}

Approximal dental caries usually develops just below the contact-point of two teeth. To treat this type of caries, undermined enamel is removed to reach the affected dentin. As a result, the outline of the prepared lesion is often below the gingival margin, and the restoration material is in direct contact with gingival epithelial cells. Today, most caries are restored using resin composites. These composite restorations consist of an organic matrix, which is a mixture of various methacrylate monomers, in combination with co-monomers of lower viscosity such as triethyleneglycol dimethacrylate (TEGDMA), initiators and contaminants (Shehata et al., 2013; Van Landuyt et al., 2011). Within this matrix, inorganic filler particles are embedded, which improves the properties of the resin-composite restoration. After the polymerization process, which is initiated by blue light at a wavelength of $400-490 \mathrm{~nm}$, these monomers will cross-link and form polymers around the filler particles (Chen, 2010). However, in many cases, the polymerization is incomplete and leaching of the unbound monomers from the surface is inevitable (Van Landuyt et al., 2011). It should be noted that the leakage is not only limited to (co-)monomers, but also leakage of initiators, inhibitors and stabilizers has been shown (Van Landuyt et al., 2011). On average, approximately $15-50 \%$ of the monomers remain unbound (Salehi et al., 2015). Depending on the material, most of the monomer leakage takes place between 0 and $8 \mathrm{~d}$ following restoration; but thereafter, leakage of (co)monomers can take place for years (Salehi et al., 2015).

Dental restorations have been associated with increased gingival inflammation (Burns et al., 2003; 
Cazzaniga et al., 2015). Factors that could lead to gingival inflammation not only include the potential for plaque retention at the margins of restoration, but also the cytotoxicity of the resin-composite restorations themselves and have been extensively studied in vitro (Geurtsen and Leyhausen, 2001). In their study, Shehata et al. (2013) showed that all tested monomers and co-monomers had a dosedependent cytotoxic effect on gingival fibroblasts. This cytotoxicity resulted in both cell necrosis and apoptosis. The changes associated with the passive process of cell necrosis was swelling of the membrane followed by rupture and lysis, while during the active process of apoptosis, condensation and fragmentation of the cytoplasm and nucleus occurred with a normal organelle structure (Shehata et al., 2013).

Beside its toxic effects, TEGDMA also affects the cells' viability (Engelmann et al., 2002; Stanislawski et al., 2003; Stanislawski et al., 2000). Furthermore, studies have shown that epithelial cell attachment to resin composites is significantly reduced, compared to various materials used as controls (Abdulmajeed et al., 2014; Al-Hiyasat et al., 2012; Camp et al., 2003; Hakki et al., 2012; Huang et al., 2002). Increased production of pro-inflammatory cytokines has also been shown for various cells when in contact with different (co-)monomers (Borzangy et al., 2013; Longo et al., 2016; Schmalz et al., 2000). These effects were shown for human buccal epithelial cells, human epidermal keratinocytes, human pulpal-, gingivaland periodontal fibroblasts, and mouse embryonic fibroblasts.

Restoring a prepared cavity with resin composite is very much dependent on the quality and depth of cure; intensity of the blue light, as well as curing times are important parameters. The restoration can easily remain only partially cured in the deeper layers, with resin components subsequently leaching out as a result. To overcome the biocompatibility problems of the leaching monomers, manufacturers have tried to develop a resin composite without the TEGDMA co-monomer. One of these composite restorations is ELS (Saremco dental AG, Rebstein, Switzerland). The manufacturers claim a more biocompatible restoration due to lack of TEGDMA.

The purpose of the present study was to assess epithelial cell attachment to 2 composite specimens of the most used commercial resin composites, with and without TEGDMA, that were well- or partially cured. As a secondary aim, inflammatory effects of the resin composite on the gingival epithelial cells were studied by measuring the cytotoxicity, viability and gene expressions encoding for attachment-related proteins, apoptosis, ROS-production, pro-inflammatory cytokines and matrix metalloproteinases.

\section{Materials and Methods}

The commercially often used Filtek Supreme XTE shade-A3D (3M ESPE, St. Paul, USA) resin composite and the ELS shade-A2 (Saremco dental AG, Rebstein, Switzerland) resin composite without TEGDMA monomers were used in this study (Table 1). Cell cultures of the human gingival epithelial cell line Ca922 , kindly provided by Dr. D. Deng Department of Preventive Dentistry, Academic Centre for Dentistry Amsterdam (ACTA), were grown on specimens of the polymerized resins.

\section{Composite specimens}

Disc-shaped specimens of the resin composites, with a diameter of $5.3 \mathrm{~mm}$ and a height of $1 \mathrm{~mm}$, were prepared using plastic ring molds (Jeveka, Almere, The Netherlands) under the following conditions: fully cured Supreme XTE (XTEH), partially cured Supreme XTE (XTES), fully cured ELS (ELSH) and partially cured ELS (ELSS). To achieve the correct Vickers micro hardness for 'partially cured' composite, as used in clinics for the bulk-fill technique, 3 composite discs were placed on top of each other - separated by microscopy glass cover slips (0.13-0.17 mm thick) (Duran Group, Mainz, Germany). Standard microscopy glass slides $(1.0 \mathrm{~mm}$ thick) (Thermo scientific, Gerhard Menzel GmbH, Braunschweig, Germany) were placed on top and underneath the top and bottom discs, respectively. This composite 'bulk sandwich' assembly was then cured for $10 \mathrm{~s}$, using an Epilar S10 curing light unit (3M EPSE, St. Paul, USA) in standard mode (998 mW/ $\mathrm{cm}^{2}$ ) with a cylindrical curing tip. The irradiance was measured using a Cure Rite ${ }^{\circledR}$ Visible curing light meter (Densply, Milford, DE, USA), according to the manufacturer's guidelines. Next, the polymerized top

Table 1. The content of used resin composite materials. Bis-GMA: bisphenol A-glycidyl methacrylate; UDMA: urethane dimethacrylate; TEGDMA: triethylene glycol dimethacrylate; PEGDMA: poly(ethylene glycol) dimethacrylate; bis-EMA: bisphenol A diglycidyl methacrylate ethoxylated.

\begin{tabular}{|c|c|}
\hline Resin composite & Content \\
\hline Filtek Supreme XTE & $\begin{array}{l}\text { - Resin content: non-aggromerated/non-aggregated } 20 \mathrm{~nm} \text { silica filler, a non- } \\
\text { aggromerated/non-aggregated } 4-11 \mathrm{~nm} \\
\text { - Filler content: zirconia and aggregated zirconia/silica filler, Bis-GMA, UDMA, } \\
\text { TEGDMA, PEGDMA and bis-EMA. }\end{array}$ \\
\hline ELS & $\begin{array}{l}\text { - Resin content: ethoxylated BisGMA, dl-Bornan-2,3dion, iron oxide black, } \\
\text { diiron trioxide red } \\
\text { - Filler content: BaAlBSi, silanized, ø } 0.70 \mu \mathrm{m}, \max 2.6 \mu \mathrm{m} \mathrm{Si0}{ }_{2} \text {, silanized, } \\
\varnothing 0.04 \mu \mathrm{m} \text { Ytterbium(III) fluoride }\end{array}$ \\
\hline
\end{tabular}


and bottom resin-composite discs were removed from the plastic ring molds with an Ash 207/208 dental instrument (Densply, Zoetermeer, the Netherlands) and placed directly into wells of a cell culture well plate and covered with a carton box to ensure that no additional light reached the specimens. Cells were then added to the well plates containing the resin-composite specimens, for culturing, within $2 \mathrm{~h}$.

\section{Bovine enamel specimens}

In order to mimic adhesion to human tooth-like biological material, control bovine-tooth enamel specimens were prepared by extracting the incisors from a bovine jaw and, using a hollow burr (diameter $6 \mathrm{~mm}$ ), cylindrical-shaped specimens were prepared from these teeth. Bovine and not human teeth were used to obtain homogeneous critical-sized areas of tooth enamel (5.3 $\mathrm{mm}$ diameter $\times 1 \mathrm{~mm}$ height). These specimens were ground using SiC abrasive paper MicroCut ${ }^{\mathrm{TM}} 600$ grit [P1200] discs (Buehler CarbiMet $^{\mathrm{TM}}$, Lake Bluff, IL, USA) until a thickness of about $1 \mathrm{~mm}$ (range 1.5 - $0.5 \mathrm{~mm}$ ) was achieved.

\section{Cell culture}

Cells from the human gingival epithelial cell line Ca922, in passages 25-26, were cultured in Dulbecco's modified Eagle's medium (DMEM) F12 medium (Thermo Fisher Scientific, Waltham MA, USA) with $10 \%$ fetal calf serum (FCI) (HyClone I, Thermo Fisher Scientific) and $1 \%$ penicillin-streptomycin-fungisone (PSF) (Sigma-Aldrich, St. Louis, MO) at $37^{\circ} \mathrm{C}$ and $5 \%$ $\mathrm{CO}_{2}$ for at least $7 \mathrm{~d}$. Culture medium was changed twice a week. Before each experiment, the cells were washed with phosphate-buffered saline (PBS) and trypsinized with $0.05 \%$ trypsin-EDTA (SigmaAldrich). The cell numbers were counted using a MUSE ${ }^{\circledR}$ Cell Analyzer (Merck Millipore, Darmstadt, Germany). Cells were diluted with medium to obtain a cell density of $6.67 \times 10^{5}$ cells $/ \mathrm{mL}$.

For all experiments, sterile F-bottom 96-well plates (Greiner bio-one, Alphen aan den Rijn, the Netherlands) were used. The resin-composite, or tooth enamel, specimens with a diameter of $5.3 \mathrm{~mm}$ and a height of $1 \mathrm{~mm}$, were prepared and placed in the wells. Subsequently, $150 \mu \mathrm{L}$ of a cell suspension with a density of $1.0 \times 10^{5}$ cells/well was added to each well. The specimens were incubated at $37^{\circ} \mathrm{C}$ under $5 \% \mathrm{CO}_{2}$ for $4 \mathrm{~h}$.

\section{Cytotoxicity}

Cytotoxicity was measured using a Cytotoxicity Detection Kit (LDH) (Roche, Basel, Switzerland) according manufacturer's guidelines. This is a colorimetric assay for the quantification of cell death and cell lysis, based on measurement of lactate dehydrogenase (LDH) activity released from the cytosol of damaged cells into the supernatant.

For this experiment, 8 different conditions were measured, each repeated $4 \times$. For each resin composite type, 2 conditions of 'cured' (hard) and 'not-wellcured' (soft) specimens were prepared (top layer and bottom layer of the specimens). Bovine-tooth enamel specimens were used as controls. Another control situation used was seeding the cells in the culture wells without any added specimens. As a negative control, the cells were treated with Triton X-100 solution (final concentration $1 \%$ ) to lyse the cells. To be able to subtract the supernatant's background signal from all values, 4 wells were set up with medium only (without any cells or specimens). Following measurement, the following equation was used to analyze the data:

$$
\text { Cytotoxicity }(\%)=\frac{\text { exp. value }- \text { low control }}{\text { high control }- \text { low control }} \times 100
$$

While the experimental values were those measured in the wells with added specimens, low control was the 'normal' cell death (cells plated in wells without specimens) and the high control was cells treated with Triton X-100 (where it was expected that all cells would be dead).

\section{Cell viability}

Viability was tested by measuring the metabolic activity of cells using alamarBlue ${ }^{\mathrm{TM}}$ cell-viability reagent dye (Thermo Fisher Scientific). Positive staining with alamarBlue indicates mitochondrial activity (Springer et al., 1998). Damaged and nonviable cells have lower innate metabolic activity and generate a proportionally lower signal. For this experiment, 6 different conditions were used in quadruplicate. Again, for each resin-composite type, 2 separate specimens were made - hard and soft. The positive control was where only cells were plated in the wells, with no specimens. The background signal was measured with only medium present in the wells, with no cells or specimens. $15 \mu \mathrm{L}$ alamarBlue was added to each well and the cells were cultured for $4 \mathrm{~h}$. After $4 \mathrm{~h}$, fluorescence was measured $($ excitation $=530 \mathrm{~nm}$, emission $=590 \mathrm{~nm})$ using a Synergy spectrophotometer (Biotek, Winooski, VT, USA). The data were then normalized by dividing the values obtained by the mean of controls (cells on tissue-culture plastic) resulting in a control value of 1 .

\section{Cell attachment}

Cell attachment was measured by means of scanning electron microscopy (SEM) and confocal microscopy. The bovine-enamel and resin-composite specimens, as well as controls, used were of the same type as for the other experiments. When possible, experiments were performed in quadruplicate per condition and each experiment was performed 2 to 3 times.

After an incubation of $4 \mathrm{~h}$, the cells were fixed with $4 \%$ paraformaldehyde (PFA) for $10 \mathrm{~min}$. Thereafter, PFA was removed by washing with PBS and the specimens and stored at $5{ }^{\circ} \mathrm{C}$ until further analysis.

\section{Confocal microscopy}

To analyze the fixed cells on the specimen surfaces, using a confocal microscope (SP2, Leica, Wetzlar, 
Germany), nuclei were stained for with propidium iodide and actin was detected using Alexa Fluor ${ }^{\mathrm{TM}}$ 488 phalloidin (Thermo Fisher Scientific). Scans were made of each specimen, at 3 randomly chosen locations, using a standardized magnification of $200 \times$. Subsequently, the cells were quantified by counting the number of cells per image area. Afterwards this field-of-view count was converted to a value reflecting the total surface area of the specimen. The cell density $/ \mathrm{mm}^{2}$ was also calculated and compared between different conditions. This experiment consisted of 5 different specimen conditions: fully cured Supreme XTE (XTEH), partially cured Supreme XTE (XTES), fully cured ELS (ELSH), partially cured ELS (ELSS) and bovine enamel. The experiment was performed twice with only 1 specimen per condition analyzed by confocal microscopy each time.

\section{Scanning electron microscopy (SEM)}

After fixation of the cells with PFA, the specimens were mounted on specimen mounts and sputter coated with $1 \mathrm{~nm}$ gold. Subsequently the disc was placed in the electron microscope (SEM XL20, FEI Thermo Fisher Scientific, Eindhoven, the Netherlands) and images were acquired. The quantification of the cells was performed in a similar way to that for confocal microscopy. Of the 2 experiments performed, 2 specimens per condition were analyzed using SEM.

\section{Leakage experiment}

There is always leakage of the (co-)monomers immediately following polymerization of a resin composite. These (co-)monomers are believed to be the main reason for the cytotoxicity of the resin composite. In this experiment, the prepared resin-composite specimens were placed in medium (without cells) and incubated at $37^{\circ} \mathrm{C}$ for $8 \mathrm{~d}$. The specimens were completely submerged in $150 \mu \mathrm{L}$ of medium fluid. After this period, the (leached-out) specimens were removed, placed in a 96-well plate and cells were added to them - as described earlier. Thereafter, the cell density was evaluated using SEM and confocal microscopy. In this experiment, 4 conditions were analyzed in duplicates.

The $8 \mathrm{~d}$ conditioned (co-)monomer-rich medium was used to investigate the possible reduced attachment of cells to the plastic culturing surface of a cell-culture plate. $75 \mu \mathrm{L}$ of conditioned medium was plated into each well in a 96-well plate and $75 \mu \mathrm{L}$ of cell-rich medium (cell density of $1 \times 10^{5}$ cells/well) was added. The cells were incubated for $4 \mathrm{~h}$ in the dark at $37^{\circ} \mathrm{C}$. The supernatant was then removed, the cells were fixed with PFA and stored at $5{ }^{\circ} \mathrm{C}$ for further analysis. Nuclei were stained with DAPI and actin was stained with phalloidin, as already described, 3 digital images were taken at standardized locations and the cell numbers were quantified as mentioned above. This experiment was performed $3 \times$ with a total number of 9 specimens (1 specimen in first experiment and 4 specimens in second and third experiment).

\section{Gene expression}

qPCR was employed to determine the expression of genes related to inflammatory cytokine production (IL1B, IL6), proteolytic activity (MMP2), cytotoxicity (BCL2, BAX), ROS production (SOD2, BCL6) and attachment (ITGAV, ITGA4) - as previously described (Schoenmaker et al., 2018). Primers used are listed in Table 2. Cells were lysed using the QIAGen cell lysis buffer and RNA was isolated following the manufacturer's protocol (RNAeasy mini kit, Qiagen, Hilden, Germany). RNA concentrations were measured using a Synergy ${ }^{\mathrm{TM}}$ microplate

Table 2. List of primers for q-PCR.

\begin{tabular}{|c|c|c|c|}
\hline Primer & Sequence $5^{\prime} \rightarrow 3^{\prime}$ & Amplicon length (bp) & Ensemble gene ID \\
\hline IL1B & $\begin{array}{c}\text { CTTTgAAgCTgATggCCCTAAA } \\
\text { AgTggTggTCggAgATTCgT }\end{array}$ & 100 & ENSG00000125538 \\
\hline IL6 & $\begin{array}{l}\text { ggCACTggCAgAAAACAACC } \\
\text { ggCAAgTCTССТСАTTgAАTCC }\end{array}$ & 85 & ENSG00000136244 \\
\hline MMP2 & $\begin{array}{c}\text { CCCTCgCAAgCCCAAgT } \\
\text { TgggTCCAgATCAggTgTgTAg }\end{array}$ & 72 & ENSG00000087245 \\
\hline BCL2 & $\begin{array}{l}\text { AgAgCCTTggATCCAggAgAA } \\
\text { gCTgCATTgTTCCCATAgAgTTC }\end{array}$ & 65 & ENSG00000171552 \\
\hline$B A X$ & $\begin{array}{l}\text { TgTCgCССТTТTCТАСТTТgC } \\
\text { CTgATCAgTTCCggСАССТT }\end{array}$ & 71 & ENSG00000087088 \\
\hline SOD2 & $\begin{array}{l}\text { AATCAggATCCACTgCAAggA } \\
\text { CgTgCTCCCACACATCAATC }\end{array}$ & 66 & ENSG00000112096 \\
\hline$B C L 6$ & $\begin{array}{c}\text { CATggAgCCTgAgAACCTTgA } \\
\text { CATggACCTgTTAACgATgTTATTg }\end{array}$ & 111 & ENSG00000113916 \\
\hline $\begin{array}{l}\text { ITGAV } \\
(\alpha V)\end{array}$ & $\begin{array}{l}\text { TACAgCAggTCCCCAAgTCACT } \\
\text { AATTCAgATTCATCCCgCAgAT }\end{array}$ & 100 & ENSG00000138448 \\
\hline $\begin{array}{l}\text { ITGA4 } \\
(V L A 4)\end{array}$ & $\begin{array}{c}\text { CgAACCgATggCTCCTAgTg } \\
\text { CACgTCTggCCgggATT }\end{array}$ & 114 & ENSG00000115232 \\
\hline
\end{tabular}


reader (Biotek, Winooski, Vermont, USA). cDNA was synthesized from $100 \mathrm{ng}$ of total RNA using reverse transcriptase and both the $\mathrm{DN}(6)$ random hexamer and oligo(dT)18 primers, according to the manufacturer's instructions, using a First Strand cDNA Synthesis Kit (Thermo-Fischer Scientific, Wilmington, DE, USA). Real-time quantitative PCR (qPCR) was performed using an ABI PRISM 7000 (Applied Biosystems, Foster City, CA). Reactions were performed in a $15 \mu \mathrm{L}$ volume containing $5 \mathrm{ng}$ cDNA, $7.5 \mu \mathrm{L}$ SYBR GreenER ${ }^{\mathrm{TM}}$ qPCR SuperMix (Invitrogen, Carlsbad, CA, USA) and $300 \mathrm{nM}$ of each primer. After an initial activation step of the hot-start DNA polymerase for $10 \mathrm{~min}$ at $95^{\circ} \mathrm{C}, 40$ cycles were run of a 2-step PCR consisting of a denaturation step at $95{ }^{\circ} \mathrm{C}$ for $30 \mathrm{~s}$ and annealing and extension step at $60{ }^{\circ} \mathrm{C}$ for $1 \mathrm{~min}$. Then, the PCR products were subjected to melting curve analysis to test if specific PCR products had been generated.

Hypoxanthine guanine phosphoribosyl transferase (HPRT) was used as the housekeeping gene. Expression of this gene was not affected by the experimental conditions. Ct values of HPRT did not differ significantly between the experimental conditions. The mRNA expression of the target genes was normalized to the expression of HPRT using the $\triangle \mathrm{Ct}$ method $\left(\mathrm{Ct}_{\text {target gene }}-\mathrm{Ct}_{\mathrm{HPRT}}\right)$ and relative mRNA expression levels of different genes were expressed as $2^{-\Delta \Delta C t}$. Both the gene expression of the cells attached to the specimens and of the cells attached to plastic surrounding the specimens were measured.

\section{Statistical analysis}

All the data were analyzed using SPSS version 23 (IBM SPSS Statics 23, Armonk, NY, USA) and GraphPad Prism (version 6.00 for Windows, GraphPad Software, La Jolla, CA, USA). Statistical significance was determined by one-way analysis of variance (ANOVA) and post hoc Tukey's test. $p$-values $<0.05$ were considered significant. Gene expressions

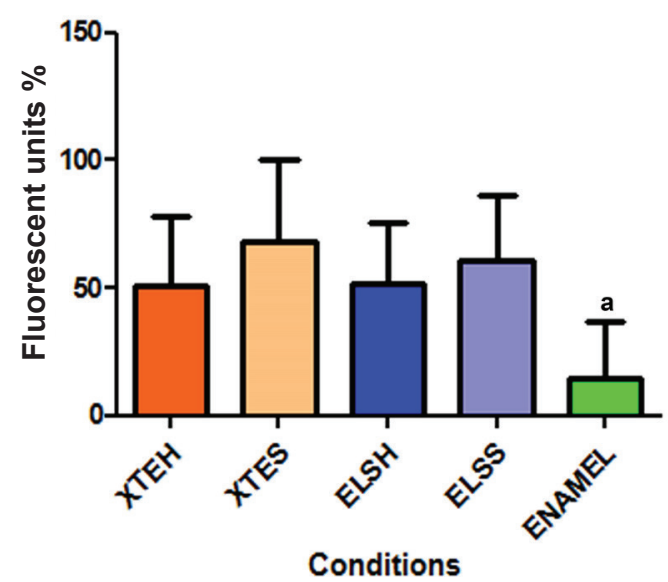

Fig. 1. Cytotoxicity of the cells in the presence of different specimens, as determined by fluorescent units. Cytotoxicity measured using LDH-assay. a Significantly different $(p<0.05)$ from XTEH, XTES, ELSH and ELSS; $n=12$. by qPCR showing at least a 2-fold difference in expression compared to other conditions and being statistically significant, were considered biologically relevant.

\section{Results}

To evaluate the reaction of the Ca9-22 gingival epithelial cells to 2 resin-composite specimen types (XTE and ELS) the following parameters were measured: cytotoxicity and viability, cell attachment and gene expressions.

\section{Cytotoxicity and viability}

In order to evaluate the biocompatibility of both types of resin-composite specimens, well- or partially-cured, their cytotoxic effects were analyzed. The leakage of $\mathrm{LDH}$, as a measure for cytotoxicity, was higher in supernatants from resin-composite specimens when compared to tooth-enamel specimens (cytotoxicity on average XTEH: $35 \%$, XTES: 57 \%, ELSH: $41 \%$, ELSS: $51 \%$, tooth enamel: $1 \%$ ) (Fig. 1). Although the partially-cured resin-composite specimens appeared to be cytotoxic, the differences from controls were not significant. To further evaluate the effects of the various resin composites, the effects on the relative metabolic activity of the cells was assessed. Mitochondrial activity was assessed using the alamarBlue assay. Cells attached to ELS showed a trend for higher metabolic activity, when compared to controls, but did not appear to differ significantly from those on XTE specimens (Fig. 2).

\section{Cell attachment}

To study the effect of resin composites upon cell attachment, $1 \times 10^{5}$ cells were seeded per specimen and the attachment was evaluated by both SEM and confocal microscopy (Fig. 3 and 4, respectively). Approximately $7 \times$ more cells were attached to the

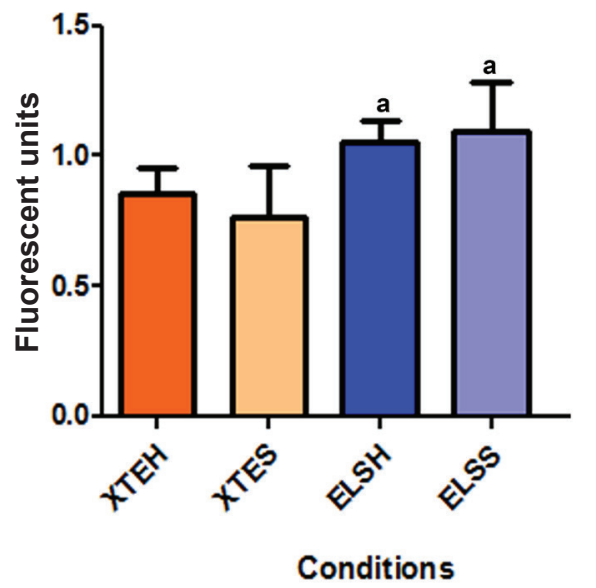

Fig. 2. Viability of the cells in the presence of different specimens, as determined by fluorescent units. Viability measured as mitochondrial activity, control (plastic) is set to $1 .{ }^{\text {a }}$ Significantly different $(p<0.05)$ from XTEH, XTES; $n=9$. 
surface of bovine-enamel specimens than the resincomposite surfaces (Fig. 5). An average of $43 \%$ of the seeded cells attached to the bovine enamel, while $5.5 \%$ attached to XTEH, $1.1 \%$ attached to XTES, $2.6 \%$ to ELSH and $4.8 \%$ to ELSS.

Since it has been shown that most leakage, of the various substances, from resin composites takes place during the first $8 \mathrm{~d}$ following polymerization (Salehi et al., 2015), cell attachment to resin-composite specimens following $8 \mathrm{~d}$ in culture medium versus that to freshly-prepared resin-composite specimens was assessed. Figs. 6 and 7 show examples of the cells attached to the surface of the resin-composite specimens that had been leached-out for $8 \mathrm{~d}$. Table 3 and Fig. 12 show the cell attachment density on these 2 specimens. It is noticeable that the number of cells attached to the leached-out specimens was 2.5 to $14 \times$ higher than to the 'freshly made' specimens, where the components had not yet leached out.

The adhesion of the gingival epithelial cells to the bottom of the well-plates was tested in the presence of medium conditioned during $8 \mathrm{~d}$ of leakage, from the 4 different conditions of resin-composite specimens. There was a clear effect on cell attachment, indicating that components that leached out of the resincomposite specimens did influence cell attachment and survival. When specimens that had leachedout in medium for $8 \mathrm{~d}$ were tested, cell attachment had returned to control levels. The conditioned medium, of XTES and both ELS specimens, showed a significant decrease of $50 \%$ or more in cell attachment to the culture plastic well-plate surface, compared to that with conditioned medium from bovine-tooth enamel specimens (Fig. 8).

\section{Effect of resin-composite characteristics on gene expression}

To assess the response of the Ca9-22 cells to the resin composites, the gene expression of a series of response genes was measured. Fig. 9 shows the results of the various gene expressions of cells attached to the specimens. Fig. 10 shows the results for cells attached to the cell-culture plastic surrounding the specimens. Inflammatory genes IL6 and MMP2 showed significant increases that were higher than the 2-fold threshold; cells attached to XTES and ELSH specimens had approximately $7 \times$ increased relative gene-expression levels compared to the control (cell culture plastic) $(p<0.05)$. Inflammatory gene IL1B showed a slight increase (less than $2 \times$ threshold) although there was a significant decrease between control samples and XTES, ELSH and ELSS (Fig. 9a).

Expression of the apoptosis inhibitor gene BCL2 was not significantly different between conditions (Fig. 9c). In contrast, the expression of $B A X$, the apoptosis promoter gene, was significantly higher; however, below the 2-fold threshold (Fig. 9c). The ratio of $B A X$ to $B C L 2$ determines the susceptibility of a cell to apoptosis. Based on this ratio (BAX : BCL2), there were no significant differences between the effects of resin-composite specimens or cell-culture plastic controls.

The expression of SOD2, a gene necessary for ROS-production and an important marker in inflammatory responses, was also not significantly different between conditions. However, expression of BCL6 in cells attached to specimens of XTES, ELSH and ELSS was $5 \times$ higher in comparison to the control (cell-culture plastic) (Fig. 9d).

The expression of the integrin component ITGAV, associated with cell-to-matrix adhesion, was not significantly different between conditions. In contrast, the expression of cell-to-cell attachment gene ITGA4 was up to $10 \times$ higher in cells attached to XTES and ELSH specimens in comparison to cell-culture plastic $(p<0.05)$ (Fig. 9e).

Notably, for the cells that are not in direct contact with the specimens, a 2-fold significant increase in IL6, MMP2, BCL6 and ITGA4 was found in cells surrounding the ELSS specimens (Fig. 10).

\section{Discussion}

In a healthy situation, junctional epithelial cells from the gingiva attach to enamel by means of hemidesmosomes and form a seal between the oralcavity ecosystem and the systemic compartments. Ideally in the clinical situation, this attachment of gingival epithelial cells to resin-composite restorations in teeth is desired in order to restore the seal between the tooth- and restoration-related biofilm and salivary bacteria on the one side and the periodontal tissues as well as the whole body on the other side.

The results of the current study showed a significantly reduced epithelial cell attachment to the surface of the resin-composite specimens when compared to tooth enamel, regardless of which different type of resin composite, with or without TEGDMA, is involved. However, no significant differences were found between the effects of welland partially-cured specimens, in terms of epithelial cell attachment. Interestingly, when cell attachment to the $8 \mathrm{~d}$ leached-out resin-composite specimens was studied, $3 \times$ more cell attachments to their surfaces were observed when compared to those on freshlymade resin-composite specimens. Clinically, these results suggested impaired epithelial attachment, in particular within the first week following placement of a subgingival resin-composite restoration. The negative effect of the leached components was further revealed by the leakage experiments, where cells that were incubated with conditioned medium attached significantly less to the well-plate surface when compared to the controls, where unconditioned medium was used. Salehi et al. (2015) showed that, in vitro, the possible toxic effects of resin composite components decreased after $7 \mathrm{~d}$ of leaching. Therefore, this could lead to considerably improved 

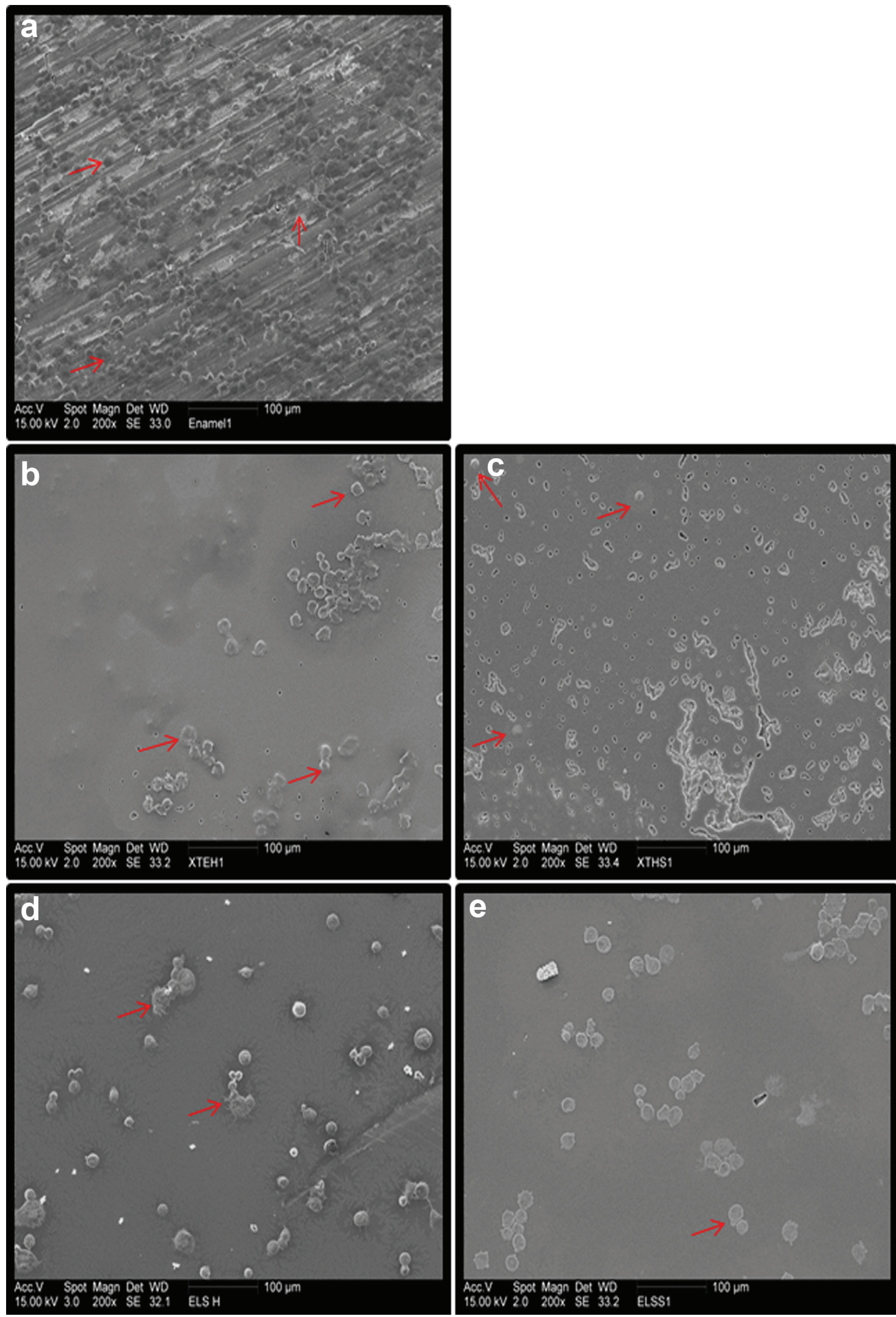

Fig. 3. Images acquired with SEM showing attachment of cells to freshly made specimens after incubation for $4 \mathrm{~h}$. Initial magnification $200 \times$. Arrows point to examples of cells. (a) Enamel, (b) XTEH, (c) XTES, (d) ELSH, (e) ELSS. 

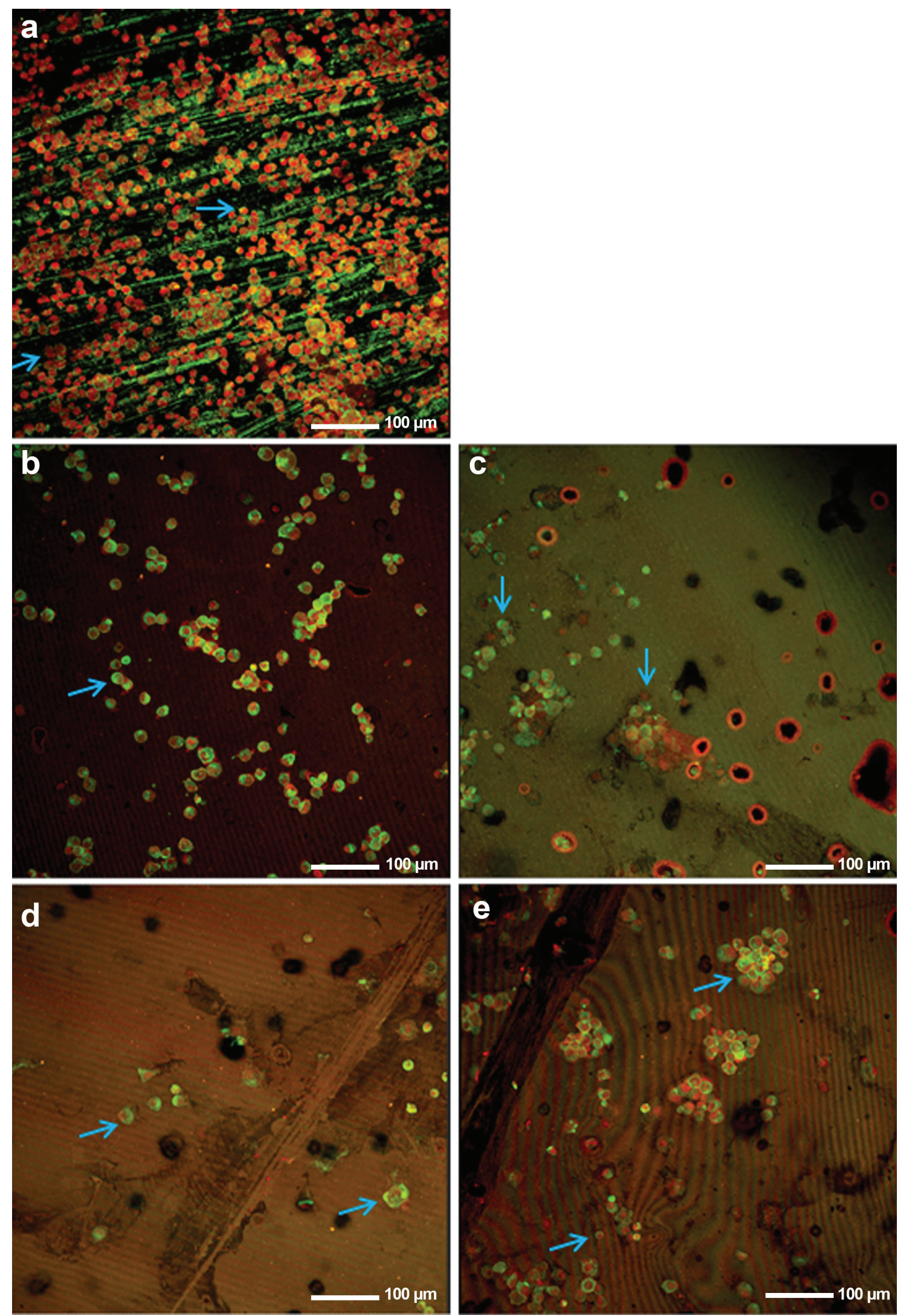

Fig. 4. Images acquired with confocal microscopy showing attachment of cells to freshly made specimens after incubation for $4 \mathbf{h}$. Initial magnification $200 \times$. Arrows point to examples of cells. (a) Enamel, (b) XTEH, (c) XTES, (d) ELSH, (e) ELSS. 
attachment when the specimens have leached-out for $8 \mathrm{~d}$. Data from the current study confirmed that the inhibition of epithelial-cell attachment was a transient phenomenon. This is of clinical importance, since it adds more solid evidence that the possible inhibition of epithelial attachment is likely to be of limited duration. Clinically, the restoration is made directly in the oral cavity and leakage of resin-composite components will take place in the immediate vicinity of the resin-composite restoration, inhibiting epithelial attachment to the restoration surface. It could also be that the positive leached-out effect is reached much faster in the human mouth than in the experimental $8 \mathrm{~d}$, since all leached-out monomers will immediately be abducted by the continuous swallowing of saliva. The mechanisms of a low cell-attachment to fresh composite specimens (restorations in the mouth) remain unknown. The cell-to-cell attachment gene ITGA4 in this study is more highly expressed in cells that are in contact with resin-composite specimens when compared to cells adjacent to the specimen. The increased expression of ITGA4 could indicate that cells on the resin composites may search actively for neighboring cells to facilitate binding.

The use of SEM and confocal microscopy yielded comparable results, indicating that either microscope can be used to assess cell attachment. As suggested by Attik et al. (2014), the use of microscopy is an efficient method to evaluate the cyto-compatibility of dental composites. In the current study, the SEM images showed attachment of cells to the surface of resincomposite specimens. It may be concluded that, even though the cells do not preferably attach to the resin composite, the appearance of the cells attached to the resin-composite surface seem to be comparable to the cells that are attached to tooth enamel. Furthermore, it could be speculated that surface roughness of the enamel might enhance the cell attachment to these control specimens. However, the attachment of cells to rough parts of resin-composite specimens seem to be considerably less than to enamel specimens (Fig. 11).

This in vitro study showed that resin-composite restorations inhibit gingival epithelial-cell attachment, at least within the first week following polymerization. These materials could steer inflammation in a certain direction, with higher IL6, MMP2 and BCL6 expressions. Although the in vitro results indicated a favorable attachment after $8 \mathrm{~d}$, by that time in vivo there is bacterial colonization and organized biofilm on the surface of the restoration - inhibiting attachment of gingival epithelial cells. The biofilm may induce gingival inflammation and this then can aid the shift of a non-inflammation-causing bacterial community into a more pathogenic biofilm, which in turn could lead to progression of limited gingivitis into periodontitis in susceptible patients (Hajishengallis, 2014; Loos and Van Dyke, 2020). Another interesting aspect that needs to be addressed is the fact that TEGDMA co-monomers are water

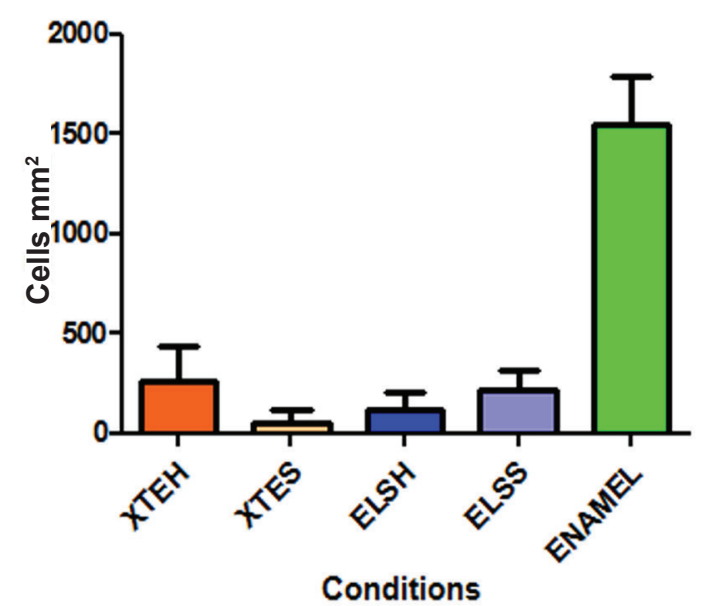

Fig. 5. Cell attachment to specimens. $n=3$.

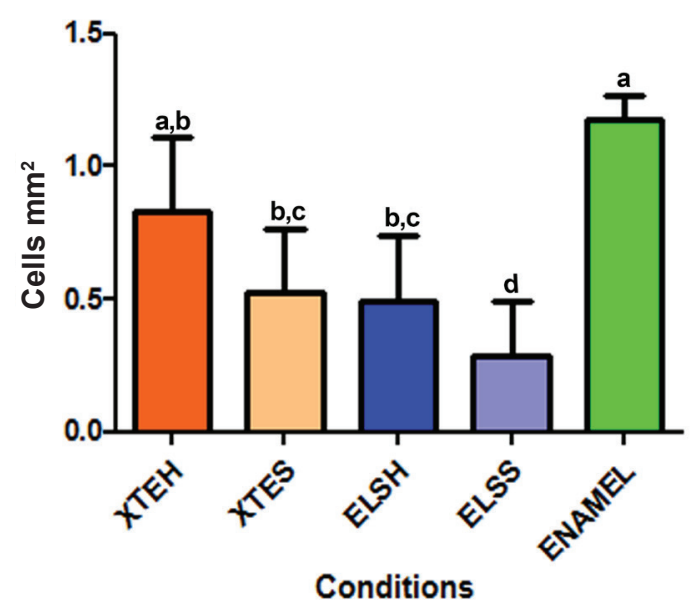

Fig. 6. Attachment of cells to the plastic surface of well plates in the presence of conditioned medium. ${ }^{\text {a-d }}$ The same letter means no statistically significant difference $(p<0.05) ; n=9$.

soluble. These components can easily leach-out from the resin-composite materials, in the presence of fluids such as gingival crevicular fluid. When the crevicular fluid is mixed with saliva in the oral cavity, the negative effects of TEGDMA, may be washed away and may reduce its toxic effect on the oral mucosa. Nevertheless, trace amounts in the oral cavity and in other organs, due to swallowing, may have harmful effects (Lyapina et al., 2014; Scott et al., 2004; Stanley, 1992; Tillberg et al., 2009).

Cytotoxicity caused by components of resin composite has been researched extensively in the past (Englemann et al., 2001; Geurtsen and Leyhausen, 2001; Goldberg, 2008; Lefebvre et al., 1996; Yoshii, 1997). The extent of the cytotoxic effect is material-, dose- and cell-type dependent (Attik et al., 2013; Geurtsen and Leyhausen, 2001; Quinlan et al., 2002; Salehi et al., 2015; Shafiei et al., 2014). Various components of resin composite can lead to cell-death, as shown in previous studies (Attik et al., 2013; Geurtsen and Leyhausen, 2001; Quinlan et al., 2002; Salehi et al., 2015; Shafiei et al., 2014). The results from the current study demonstrate that the cytotoxicity, 


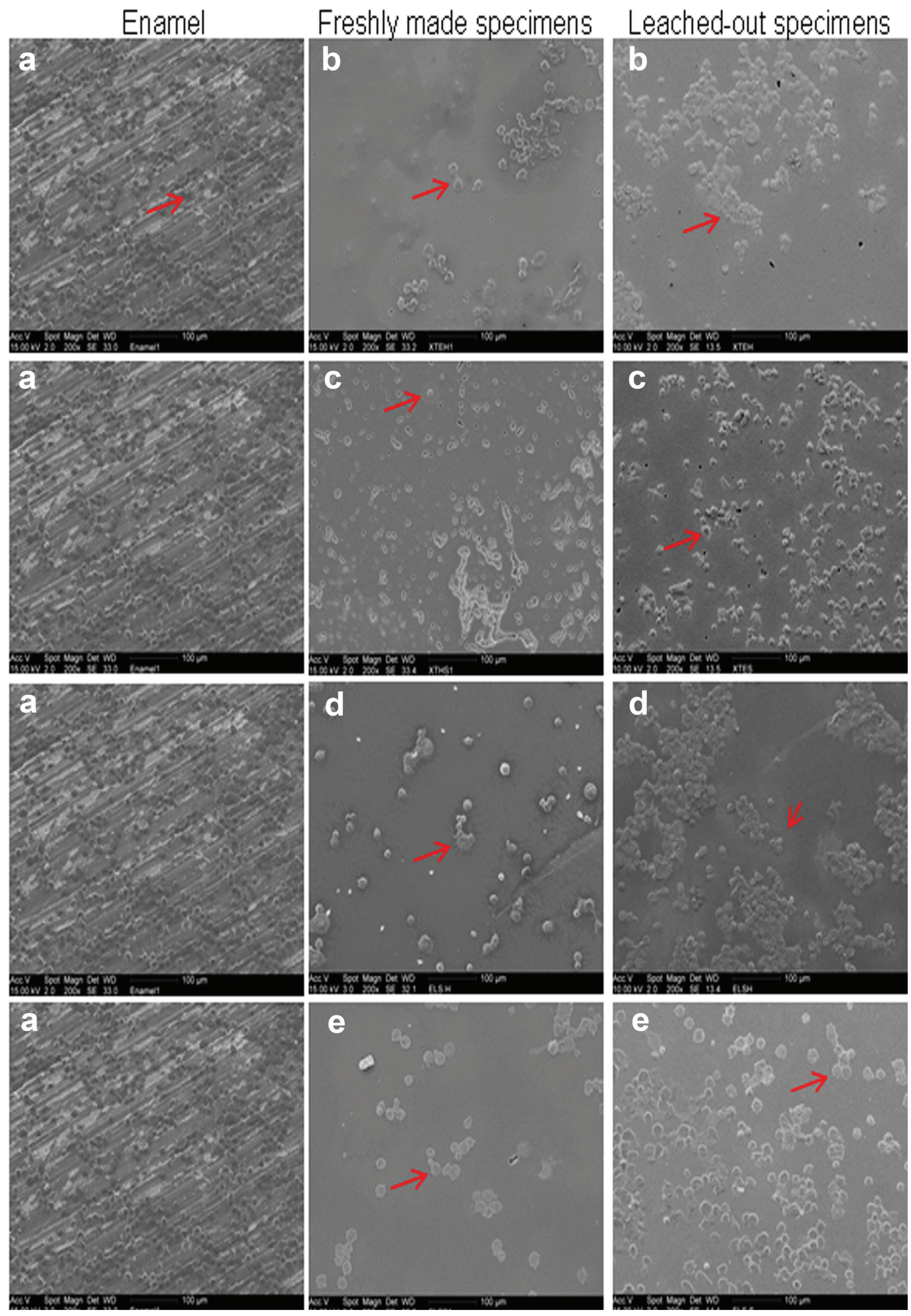

Fig. 7. Images acquired by SEM showing attachment of cells to enamel, freshly made and leached-out specimens after incubation for $4 \mathrm{~h}$. Initial magnification $200 \times$. Arrows point to examples of cells. (a) Enamel, (b) XTEH, (c) XTES, (d) ELSH, (e) ELSS. 

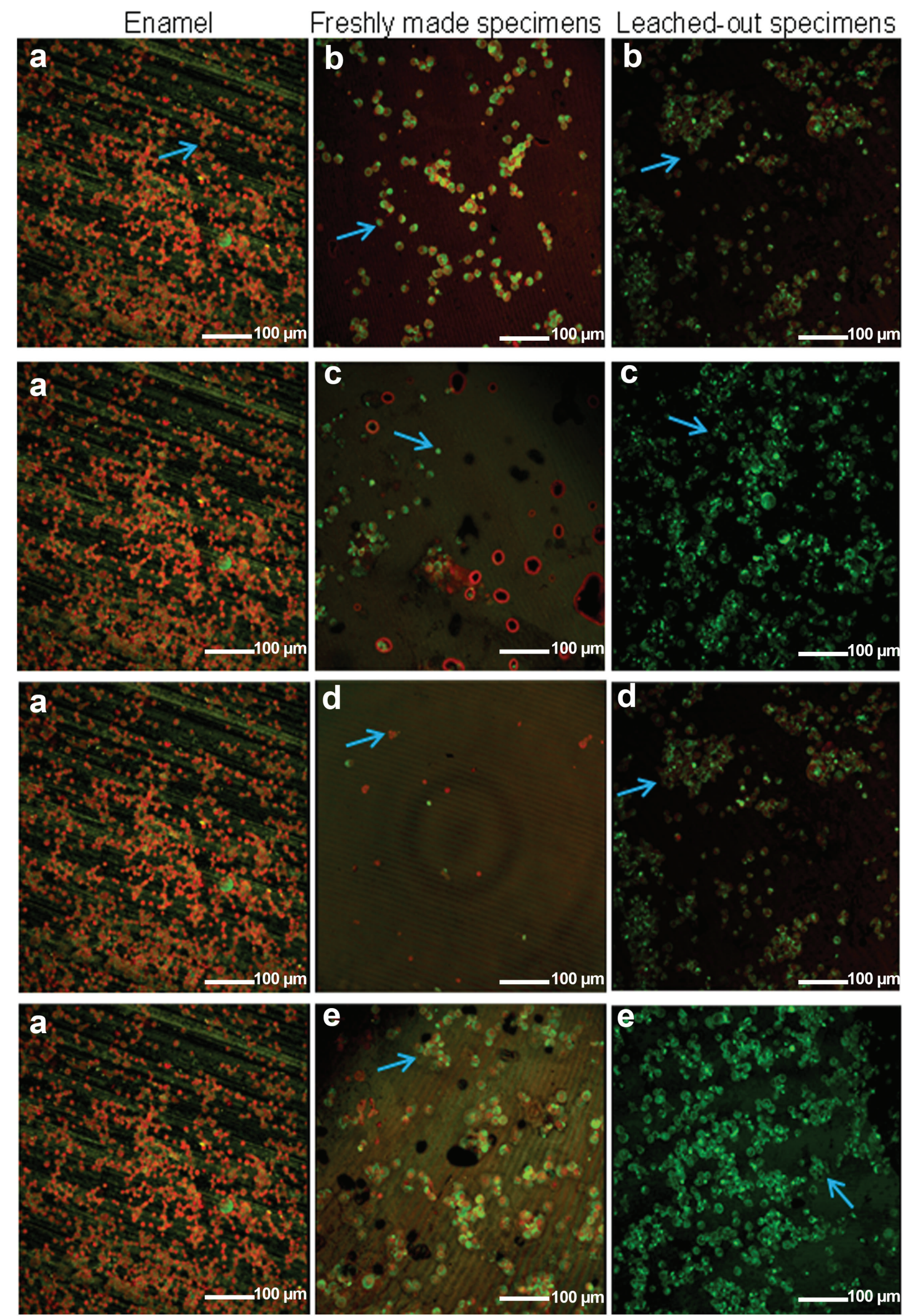

Fig. 8. Images acquired by confocal microscopy showing attachment of cells to enamel, freshly made and leached-out specimens after incubation for $\mathbf{4} \mathbf{h}$. Initial magnification $200 \times$. Arrows point to examples of cells. (a) Enamel, (b) XTEH, (c) XTES, (d) ELSH, (e) ELSS. 

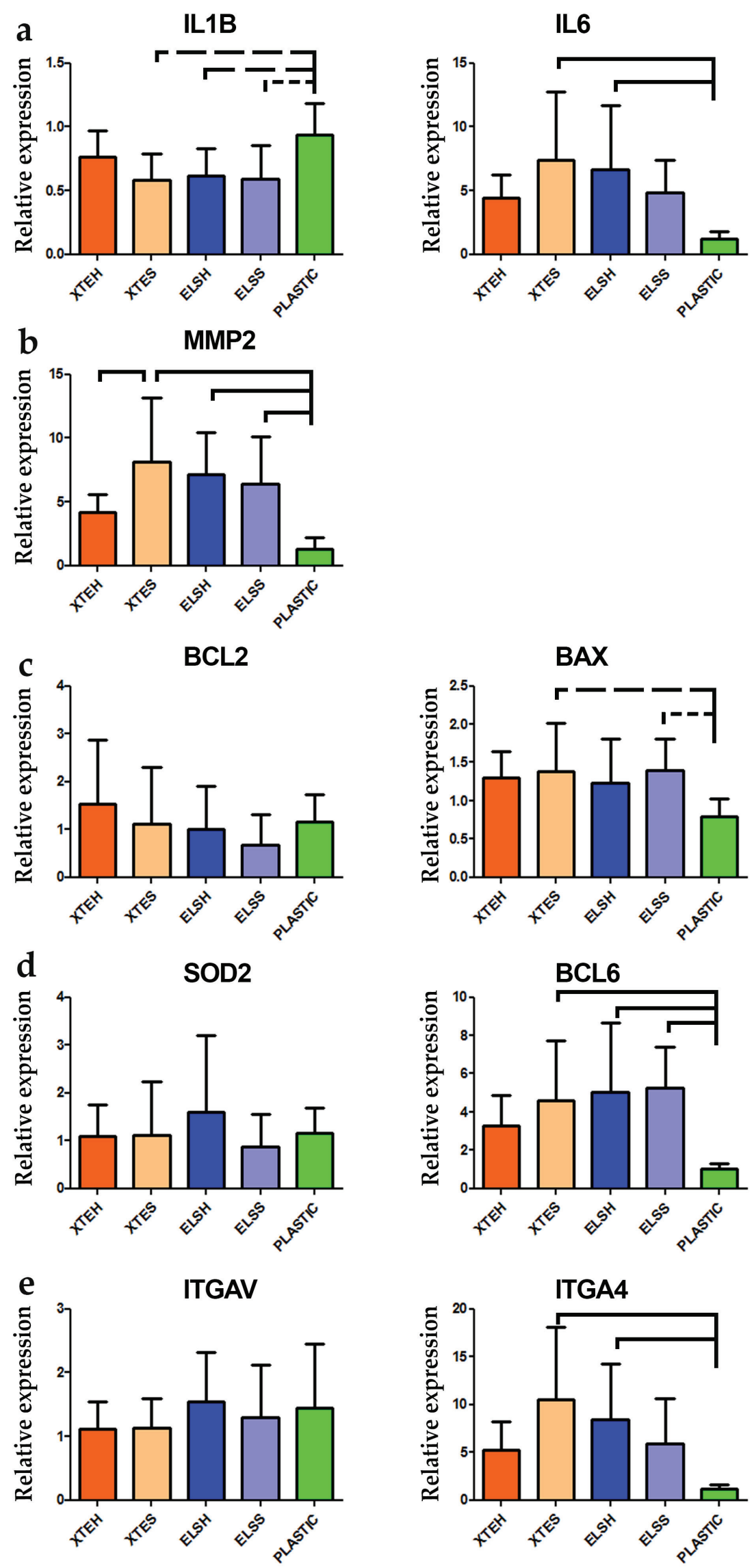

Fig. 9. Gene-expressions of the cells attached to specimens, measured using qPCR. (a) Inflammatory cytokines: IL1B and IL6; (b) Matrix metalloproteinase: MMP2; (c) Apoptosis genes: BCL2 and BAX; (d) ROS production genes: SOD2 and BCL6; (e) Attachment genes: ITGAV $(\alpha V)$ and ITGA4 (VLA4). Connectors show the significant differences $(p<0.05)$ with $>2$-fold difference in expression between conditions. Dotted connectors show the significant differences $(p<0.05)$ but not reaching the 2 -fold threshold between conditions. $n=12$. 

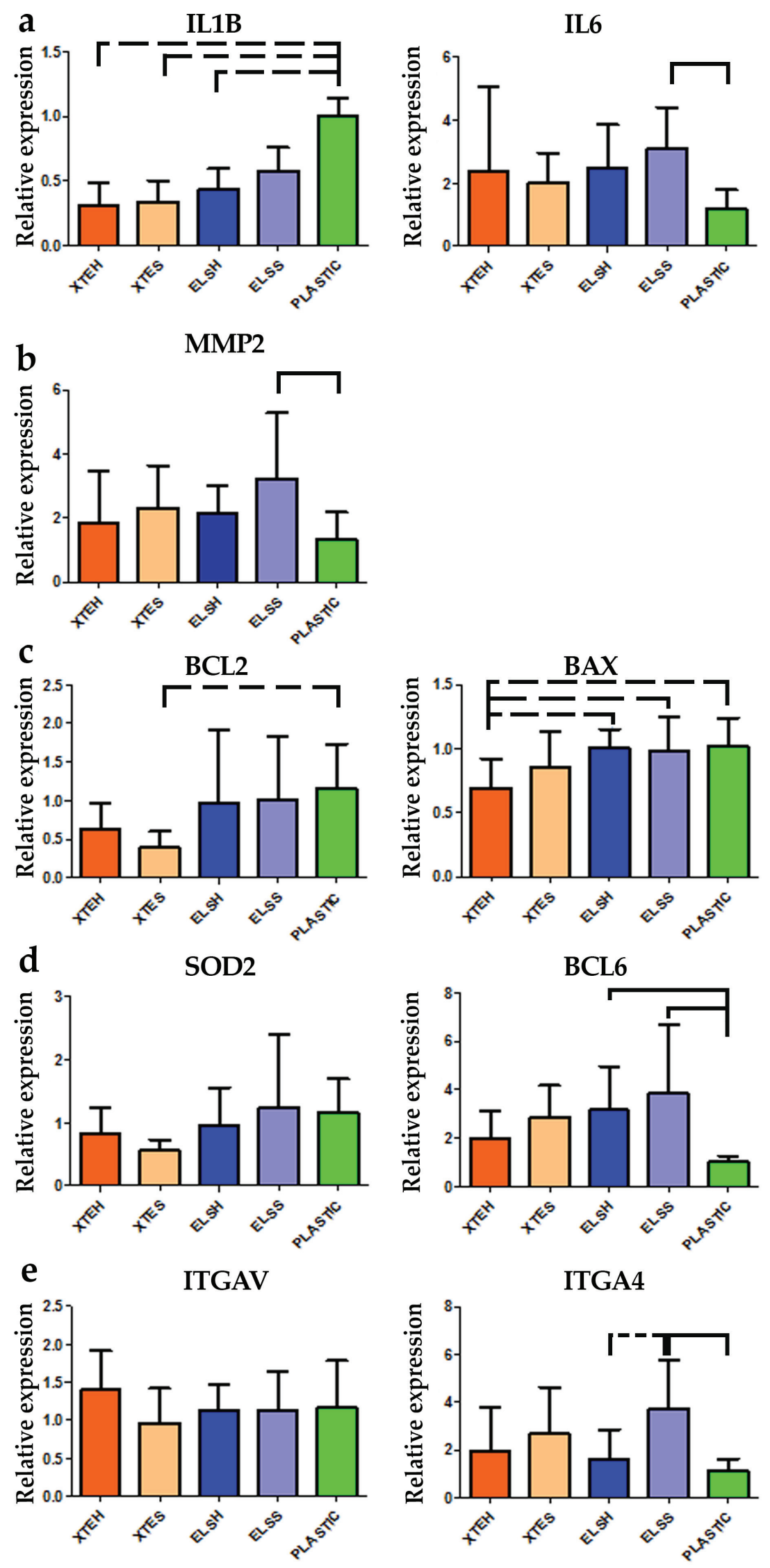

Fig. 10. Gene-expressions of the cells attached to plastic around the specimens, measured using qPCR. (a) Inflammatory cytokines: IL1B and IL6; (b) Matrix metalloproteinase: MMP2; (c) Apoptosis genes: BCL2 and $B A X$; (d) ROS production genes: SOD2 and BCL6; (e) Attachment genes: ITGAV ( $\alpha \mathrm{V})$ and ITGA4 (VLA4). Connectors show the significant differences $(p<0.05)$ with $>2$-fold difference in expression between conditions. Dotted connectors show the significant differences $(p<0.05)$ but not reaching the 2-fold threshold between conditions. $n=12$. 

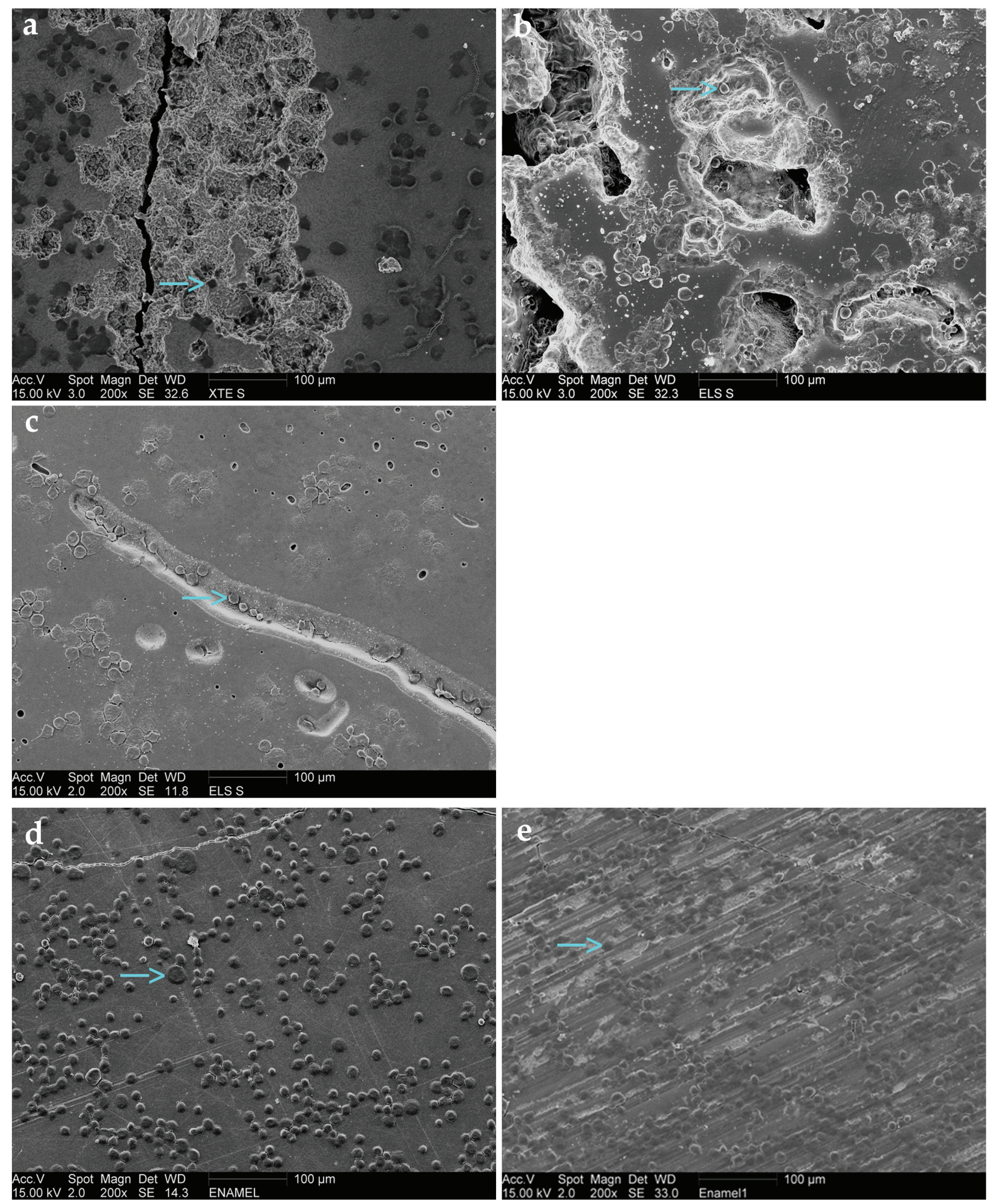

Fig. 11. Images acquired with SEM showing attachment of cells to freshly made specimens after incubation for $4 \mathrm{~h}$. Initial magnification $200 \times$. Arrows point to examples of cells. (a-c) Cell attachment to the rough surfaces of the XTES and ELSS specimens appears not to be different or less than to the smooth surfaces of the specimens. (d-e) Cell attachment to the smooth surface of an enamel specimen is comparable to that of rough surfaced specimen.

as measured by LDH, is significantly higher in cells seeded on resin-composite specimens than on tooth enamel.

As the PCR-results did not show higher apoptoticgene expressions ( $B A X$ and BCL2), it could be hypothesized that the cell-death measured by the LDH-assay is caused by necrosis rather than apoptosis. The ratio of the BCL2:BAX predetermines the cell's susceptibility to apoptosis. For apoptosis to occur, a certain threshold needs to be reached. An external stimulus, such as components from a resin composite, can influence this ratio (Oltvai, 1994). In the current study, there were no significant differences in the $B C L 2: B A X$ ratio among the 
various resin composite conditions when compared to control (cell culture plastic). Therefore, it might be concluded that the resin-composite specimens have little influence on the susceptibility of the Ca9-22 gingival epithelial cells to apoptosis. However, to further substantiate this, more apoptosis markers should be assessed.

The viability of the gingival epithelial cells, as measured by the metabolic activity of the cells, seems to be significantly increased when comparing the effects of the ELS to those of the XTE specimens. Viability results are expressed as ratios to the controls; therefore, the results do not contain the controls and the control has a value of 1 . The slightly increased viability of cells on ELS specimens and the slightly decreased viability on XTE specimens resulted in the significant differences between these 2 conditions. The increased viability with the ELS specimens could be due to over-activity of the cells, when they are in contact with this type of composite.

The increased expression of IL6, MMP2 and BCL6 could be interpreted as an inflammatory effect of the resin-composite specimens on the gingival epithelial cells. This is in accordance with previous studies showing an increase in expression of IL6 (Schmalz et al., 2000) and MMP2 (Orsini et al., 2011), when cells come in contact with resin-composite material.

A shortcoming of the PCR analyses is that these were not performed on RNA samples of cells that were grown on the tooth-enamel samples. Yearlong experience (TS and TJdeV) has shown that, for some reason, the yield of RNA extracted from cells grown on calcified tissues is too low to perform multiple qPCRs with. However, interestingly, the clinically important parameter of cell attachment to tooth enamel, showing superior adhesion compared to all other experimental conditions, suggests that cells on this surface may respond in a similar way to cells seeded on cell culture plastic.

Standard deviations of experiments in this study should be noted and can be explained by differences in the specimens resulting from the variances in the polymerization. In specimens that were well cured, variation in polymerization could nevertheless be present - leading to differences in unbound (Co-) monomers that can then leach out. The degree of polymerization in partially-cured specimens could also vary, leading to differences in attachment of the cells to various specimens made from the same material and condition. By using the current research protocol, the leachable components originating from the resin-composite specimens are closely related to reality in a dental practice, and the variability is the result of differences within the restoration material. To prevent further variability, gingival epithelial cell-line Ca9-22 was used in this study. The advantage of using an immortalized cell-line is the small inter-batch-variability (Schmalz, 1994). Another shortcoming of this study was the use of conditioned plastic, instead of tooth enamel specimens, as controls for measuring the $\mathrm{qPCR}$ results. However, from previous experiments, the authors have noticed that the yield of RNA is very low when comparing cells grown on tooth enamel specimens to those on cell culture plastic. As it was desirable to analyze many genes, it was decided to compare gene expressions of cells cultured on plastic as controls.

The results of the current study further suggested that, despite the lack of TEGDMA co-monomer in the ELS-specimen, the same effects on cells were observed as with the TEGDMA-containing resin composite Supreme XTE, in terms of cytotoxicity, viability, inflammatory gene expressions and epithelial cell attachment. Clearly other leaching components (Van Landuyt et al., 2011) of resin composites could also play a major role in the attachment, cytotoxicity, viability and gene expressions of the Ca9-22 gingival epithelial cells.

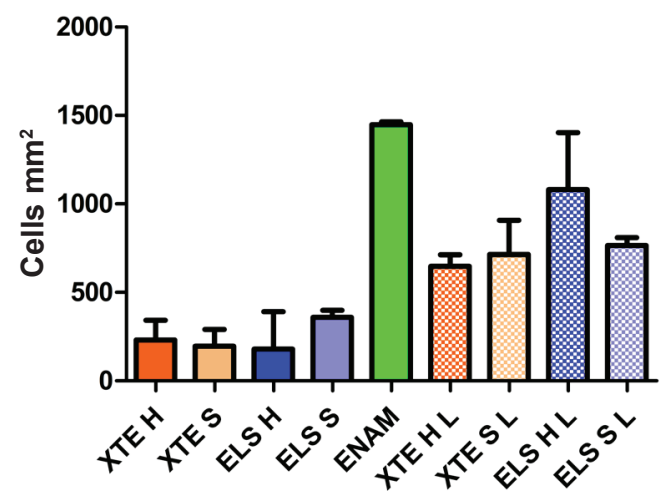

Fig. 12. Cell attachment to freshly made specimens and leached-out specimens. $\mathrm{L}=$ leached-out specimens. $n=2$.

Table 3. Cell density of attached cells to the leached-out specimens. One experiment, $n=2$.

\begin{tabular}{|c|c|c|}
\hline Conditions & 'Freshly-made' specimens cells/mm² & 'Leached-out' specimens cells/mm² \\
\hline XTE H & $\begin{array}{l}\text { Specimen 1: } 309 \\
\text { Specimen 2: } 151\end{array}$ & $\begin{array}{l}\text { Specimen 1: } 694 \\
\text { Specimen 2: } 602\end{array}$ \\
\hline XTE S & $\begin{array}{l}\text { Specimen 1: } 263 \\
\text { Specimen 2: } 127\end{array}$ & $\begin{array}{l}\text { Specimen 1: } 851 \\
\text { Specimen 2: } 578\end{array}$ \\
\hline ELS H & $\begin{array}{l}\text { Specimen 1: } 329 \\
\text { Specimen 2: } 30\end{array}$ & $\begin{array}{l}\text { Specimen 1: } 1308 \\
\text { Specimen 2: } 855\end{array}$ \\
\hline ELS S & $\begin{array}{l}\text { Specimen 1: } 387 \\
\text { Specimen 2: } 330\end{array}$ & $\begin{array}{l}\text { Specimen 1: } 731 \\
\text { Specimen 2: } 796\end{array}$ \\
\hline ENAMEL & $\begin{array}{l}\text { Specimen 1: } 1459 \\
\text { Specimen 2: } 1436\end{array}$ & - \\
\hline
\end{tabular}




\section{Conclusions}

Resin composites, with and without TEGDMA, wellor partially-cured, negatively affect the attachment of Ca9-22 gingival epithelial cells and have cytotoxic and inflammatory effect on these cells. However, these effects seem transient since the potential for adhesion of epithelial cells to specimens that have leached out, for at least a week, increases considerably. During that period, a new biofilm on the restoration surface could, possibly, still inhibit the junctional epithelial cells from forming a proper seal for the body against the hostile oral environment.

\section{Acknowledgements}

We would like to thank the laboratory co-workers of departments of cell biology and dental material sciences for their assistance in the lab, specially A. Werner for assisting with SEM analysis. Special thanks to the Dutch Society of Periodontology (NVvP), for their financial contribution to this project. The authors declare no potential conflicts of interest and do not have any financial interest in the companies whose materials are included in this article.

\section{References}

Abdulmajeed AA, Walboomers XF, Massera J, Kokkari AK, Vallittu PK, Narhi TO (2014) Blood and fibroblast responses to thermoset BisGMATEGDMA/glass fiber-reinforced composite implants in vitro. Clin Oral Implants Res 25: 843-851.

Al-Hiyasat AS, Al-SA'eed OR, Darmani H (2012) Quality of cellular attachment to various root-end filling materials. J Appl Oral Sci 20: 82-88.

Attik GN, Gritsch K, Colon P, Grosgogeat B (2014) Confocal time lapse imaging as an efficient method for the cytocompatibility evaluation of dental composites. J Vis Exp 9: e51949. DOI: 10.3791/51949.

Attik GN, Pradelle-Plasse N, Campos D, Colon P, Grosgogeat B (2013) Toxicity evaluation of two dental composites: three-dimensional confocal laser scanning microscopy time-lapse imaging of cell behavior. Microsc Microanal 19: 596-607.

Borzangy S, Labban N, Windsor LJ (2013) Effects of interim acrylic resins on the expression of cytokines from epithelial cells and on collagen degradation. J Prosthet Dent 110: 296-302.

Burns DR, Beck DA, Nelson SK, Committee on Research in Fixed Prosthodontics of the Academy of Fixed P (2003) A review of selected dental literature on contemporary provisional fixed prosthodontic treatment: report of the Committee on Research in Fixed Prosthodontics of the Academy of Fixed Prosthodontics. J Prosthet Dent 90 :474-497.
Camp MA, Jeansonne BG, Lallier T (2003) Adhesion of human fibroblasts to root-end-filling materials. J Endod 29: 602-607.

Cazzaniga G, Ottobelli M, Ionescu A, GarciaGodoy F, Brambilla E (2015) Surface properties of resin-based composite materials and biofilm formation: a review of the current literature. Am J Dent 28: 311-320.

Chen MH(2010) Update on dental nanocomposites. J Dent Res 89: 549-560.

Engelmann J, Leyhausen G, Leibfritz D, Geurtsen W (2002) Effect of TEGDMA on the intracellular glutathione concentration of human gingival fibroblasts. J Biomed Mater Res 63: 746-751.

Englemann J, Leyhausen G, Leibfritz D, Geurtsen W (2001) Metabolic effects of dental resin components in vitro detected by NMR spectroscopy. J Dent Res 80: 869-875.

Geurtsen W, Leyhausen G (2001) Chemicalbiological interactions of the resin monomer triethyleneglycol-dimethacrylate (TEGDMA). J Dent Res 80: 2046-2050.

Goldberg M (2008) In vitro and in vivo studies on the toxicity of dental resin components: a review. Clin Oral Invest 12: 1-8.

Hajishengallis G (2014) The inflammophilic character of the periodontitis-associated microbiota. Mol Oral Microbiol 29: 248-257.

Hakki SS, Bozkurt SB, Ozcopur B, Purali N, Belli $S$ (2012) Periodontal ligament fibroblast response to root perforations restored with different materials - a laboratory study. Int Endod J 45: 240-248.

Huang FM, Tai KW, Chou MY, Chang YC (2002) Resinous perforation-repair materials inhibit the growth, attachment, and proliferation of human gingival fibroblasts. J Endod 28: 291-294.

Lefebvre CA, Schuster GS, Rueggeberg FA, TamareSelvy K, Knoernschild KL (1996) Responses of oral epithelial cells to dental resin components. J Biomater Sci Polym Ed 7: 965-976.

Longo DL, Paula-Silva FWG, Faccioli LH, GatonHernandez PM, de Queiroz AM, da Silva LAB (2016) Cytotoxicity and cytokine expression induced by silorane and methacrylate-based composite resins. J Appl Oral Sci 24: 338-343.

Loos BG, Van Dyke TE (2020) The role of inflammation and genetics in periodontal disease. Periodontol 2000 83: 26-39.

Lyapina M, Dencheva M, Krasteva A, Tzekova M, Kisselova-Yaneva A (2014) Concomitant contact allergy to formaldehyde and methacrylic monomers in students of dental medicine and dental patients. Int J Occup Med Environ Health 27: 797-807.

Oltvai ZN (1994) Checkpoints of dueling dimers foil death wishes. Cell 79: 189-192.

Orsini G, Mazzoni A, Orciani M, Putignano A, Procaccini M, Falconi M, Pashley D.H, Tay F.R, Breschi L (2011) Matrix metalloproteinase-2 expression induced by two different adhesive 
systems on human pulp fibroblasts. J Endod 37: 16631667.

Quinlan CA, Zisterer DM, Tipton KF, O'Sullivan MI (2002) In vitro cytotoxicity of a composite resin and compomer. Int Endod J 35: 47-55.

Salehi S, Gwinner F, Mitchell JC, Pfeifer C, Ferracane JL (2015) Cytotoxicity of resin composites containing bioactive glass fillers. Dent Mater 31: 195203.

Schmalz G (1994) Use of cell-cultures for toxicity testing of dental materials - advantages and limitations. J Dent 22: S6-S11.

Schmalz G, Schweikl H, Hiller KA (2000) Release of prostaglandin E2, IL-6 and IL-8 from human oral epithelial culture models after exposure to compounds of dental materials. Eur J Oral Sci 108: 442-448.

Schoenmaker T, Wouters F, Micha D, Forouzanfar T, Netelenbos C, Eekhoff EMW, Bravenboer N, de Vries TJ (2018) The effect of Activin-A on periodontal ligament fibroblasts-mediated osteoclast formation in healthy donors and in patients with fibrodysplasia ossificans progressiva. J Cell Physiol 234: 10238-10247.

Scott A, Egner W, Gawkrodger DJ, Hatton PV, Sherriff M, Van Noort R, Yeoman C, Grummitt J (2004) The national survey of adverse reactions to dental materials in the UK: a preliminary study by the UK Adverse Reactions Reporting Project. Br Dent J 196: 471-477.

Shafiei F, Tavangar MS, Razmkhah M, Attar A, Alavi AA (2014) Cytotoxic effect of silorane and methacrylate based composites on the human dental pulp stem cells and fibroblasts. Med Oral Patol Oral Cir Bucal 19: e350-e358.

Shehata M, Durner J, Eldenez A, Van Landuyt K, Styllou P, Rothmund L, Hickel R, Scherthan H, Geurtsen W, Kaina B, Carell T, Reichl FX (2013) Cytotoxicity and induction of DNA doublestrand breaks by components leached from dental composites in primary human gingival fibroblasts. Dent Mater, 29: 971-979.

Springer JE, Azbill RD, Carlson SL (1998) A rapid and sensitive assay for measuring mitochondrial metabolic activity in isolated neural tissue. Brain Res Brain Res Protoc 2: 259-263.

Stanislawski L, Lefeuvre M, Bourd K, Soheili-Majd E, Goldberg M, Perianin A (2003) TEGDMA-induced toxicity in human fibroblasts is associated with early and drastic glutathione depletion with subsequent production of oxygen reactive species. J Biomed Mater Res A 66: 476-482.

Stanislawski L, Soheili-Majd E, Perianin A, Goldberg M (2000) Dental restorative biomaterials induce glutathione depletion in cultured human gingival fibroblast: Protective effect of N-acetyl cysteine. J Biomed Mater Res 51: 469-474.

Stanley HR (1992) Local and systemic responses to dental composites and glass ionomers. Adv Dent Res 6: 55-64.

Tillberg A, Stenberg B, Berglund A (2009) Reactions to resin-based dental materials in patients-type, time to onset, duration, and consequence of the reaction. Contact Dermatitis 61: 313-319.

Van Landuyt KL, Nawrot T, Geebelen B, De Munck J, Snauwaert J, Yoshihara K, Scheers H, Godderis L, Hoet P, Van Meerbeek B (2011) How much do resin-based dental materials release? A meta-analytical approach. Dent Mater 27: 723-747.

Yoshii E (1997) Cytotoxic effects of acrylates and methacrylates: Relationships of monomer structures and cytotoxicity. J Biomed Mater Res 37: 517-524.

Editor's note: There were no questions from reviewers for this paper, so there is no Discussion with Reviewers section. The Scientific Editor responsible for this paper was Thimios Mitsiadis. 